\title{
O rei da vela e a ditadura militar
}

\author{
Seleste Michels da Rosa*
}

\begin{abstract}
Resumo: A peça ataca todos pilares da ditadura brasileira, e mesmo assim, é encenada em 67, ou seja, em pleno governo Castelo Branco em que se deu a solidificação do governo ditatorial. A nossa ditadura se construiu sobre três pilares: Deus, Pátria e Família. Essa peça destrói, questiona, transforma e desmascara cada um deles. Além disso, ela propõe uma paródia ao amor medieval explicitada pelos nomes dos protagonistas: Abelardo e Heloísa; símbolos do amor verdadeiro e acima de qualquer empecilho. Nessa paródia, o amor é totalmente relativizado e posto a serviço de outros interesses.
\end{abstract}

Palavras-chave: Ditadura; Capitalismo; Socialismo; Fascismo; Teatro político.

\begin{abstract}
The military dictatorship in 1964 was based on the triangle: God, homeland, and family. By attacking all these principles, this play managed to join all the elements that most insulted our dictatorship. Its hardest criticism regards the most worshipped pillar of this unit, namely the family. However, the writing is not limited to this matter, because it also criticizes homeland, capitalism, and our fake patriotism.
\end{abstract}

Keywords: Dictatorship; Capitalism; Socialism; Fascim; Political theater.

A ditadura militar de 64 era baseada no triângulo: Deus, pátria e família. Essa peça ataca justamente esse triângulo, assim conseguiu unir todos os elementos que mais afrontaram nossa ditadura. Suas críticas mais fortes se dão ao pilar mais cultuado dessa, a família. Contudo não se detém nesse ponto, também critica a pátria, o capitalismo e o nosso patriotismo fajuto.

A família é atacada em todas as suas bases. O homossexualismo dentro de famílias tradicionais é exposto na história de Totó. O texto também ataca o casamento e revela que por trás da união sagrada se escondem interesses financeiros. O casamento de Heloísa e Abelardo é sem dúvida um casamento regido por interesses. Essa relação se torna particularmente irônica pelo nome dado aos personagens, nomes advindos de uma história de amor medieval, onde o casal se amava tanto que correu grande risco para tentar casar.

A fidelidade conjugal também é questionada, ela não é importante frente a outros interesses. Abelardo não impede que Heloísa o traia com o americano a fim de obter com isso

\footnotetext{
* Seleste Michels da Rosa é graduada pela Universidade Federal do Rio Grande do Sul, com pesquisa na área do teatro pós-moderno. Atualmente, está vinculada ao curso de pós-graduação da Pontifícia Universidade Católica do Rio Grande do Sul, desenvolvendo diversos trabalhos centrados no 'teatro desagradável' de Nelson Rodrigues, tais como "Dorotéia: peça mítica pós-moderna", "Senhora dos Afogados e o pós-modernismo".
} 
algum lucro. A peça ainda sugere que o comportamento familiar é uma farsa mantida somente diante da sociedade. D.Poloca explica a Abelardo que embora seja sua amiga não quer expor a sociedade sua amizade com um novo rico, pois ela defende seu ponto de vista de tradição e família.

Além disso, existe também a crítica à pátria. Abelardo se queixa de viver nesse país de miseráveis com leis monstruosas que não protegem seu capital, mas protegem devedores e trabalhadores. Em uma outra passagem ao demitir um funcionário Abelardo afirma que ele ainda voltará e ficará montando guarda a sua porta com uma camisa amarela, azul ou verde e lutará contra a maré vermelha que ameaçará tomar conta do mundo. Essa passagem parece uma previsão da ditadura que se instauraria com força posteriormente lutando contra o comunismo. Outra passagem que se assemelha ao que viria depois é a seguinte:

ABELARDO - há um momento em que a burguesia abandona sua velha máscara liberal. Declara-se cansada de carregar nos ombros os ideais de justiça da humanidade, as conquistas da civilização e outras besteiras! [...] Esse momento já soou na Itália e implanta-se pouco a pouco nos países onde o proletariado é fraco ou divido. (ANDRADE, 1967, p. 75)

Com todas essas críticas explícitas ao capitalismo e ao regime ditatorial é interessante notar que essa peça foi publicada em 1933, ou seja, antes da implantação da ditadura militar no Brasil, e encenada em 1967 num de seus momentos mais rígidos. O governo militar impõe, em janeiro desse ano, uma nova Constituição para o País. Aprovada neste mesmo ano, a Constituição de 1967 confirma e institucionaliza o regime militar e suas formas de atuação.

A peça é a narração da história de Heloísa e Abelardo, ela uma aristocrata falida de família tradicional, ele um novo rico (leia-se: precisando de um sobrenome), ou seja, ambos buscando nesse casamento algo que lhes faltava. No eixo principal do enredo está essa história de amor, que trata do casamento com grande ironia. Os nomes dos protagonistas são da maior história de amor da Idade Média. Interessante que os nomes também retomam um momento de ditadura, não militar, mas religiosa, esses nomes reforçam ainda mais o contraste de um casamento feito por amor e um casamento estritamente regido por interesses.

Sendo assim, o cerne da peça ataca muito diretamente a ditadura de 64, pois apesar dessa não ser uma ditadura religiosa, a igreja católica está muito atrelada a ela e por isso seus dogmas são defendidos pelo regime: a formação de famílias é a principal marca dessa defesa. Além disso, foi a Igreja que destruiu a história de amor de Abelardo e Heloísa, no texto medieval, essa releitura poderia ser lida como uma nova crítica à Igreja.

O comportamento de Abelardo e Heloísa, na peça, vai aos poucos reforçando a crítica à família, afinal Abelardo passa todo o tempo galanteando a mãe e a tia de Heloísa, sem menor pudor disso e permite que Heloísa mantenha um relacionamento dúbio com o 
americano a fim de tirar proveito dessa situação. Dessa forma valores intrínsecos do casamento como o amor e a fidelidade são postos de lado para contemplar outros interesses.

Em termos estéticos, essa peça conjuga dois aspectos, a princípio contraditórios, o anti-realismo e a clara associação com a realidade. Contudo, em tempos de ditadura, sabemos que essa dupla é recorrente, mas o nosso caso específico, não pode ser lido como alegoria por que na maioria dos casos a associação é direta. $\mathrm{O}$ autor usa recursos brechtianos a fim de demarcar a emolduração do espetáculo. Esse efeito colabora sobremodo para reforçar a tentativa anti-realista, ou seja, o autor tenta mostrar que a peça não é a realidade para colocar mais elementos da realidade na peça, sem que isso seja entendido como crítica a realidade: “ABELARDO I - Mas essa cena basta para nos identificar perante o público. Não preciso falar com mais nenhum dos meus clientes. São todos iguais.” (ANDRADE, 1967, p. 41) Outra cena, já no ato final, marca mais vigorosamente essa tendência: “ABELARDO I - Olá! Maquinista! Feche o pano. Por um instante só.” (ANDRADE, 1967, p. 81)

Mesmo com esses esforços, a fim de impedir a total catarse, talvez feitos para 'disfarçar' a vigorosa identidade com a realidade ela mostra uma constituição ideológica inserida no real. Fala de regimes existentes na realidade como comunismo, socialismo, capitalismo, fascismo. Enfim regimes recém implantados em outros países do mundo e por isso assuntos em voga.

A peça foi publicada em 1933, ou seja, logo após o crack de 29 e a conseqüente crise cafeeira que afetou especialmente nosso país. Interessante é que esses fatos estão bem demarcados em alguns momentos da peça, ela é perfeitamente colocada no tempo e no espaço. Todas essas reviravoltas na esfera econômica, como a crise do café, provocam movimentações sociais. Por quê?

A aristocracia brasileira era basicamente dependente da monocultura do café, então quando os preços do café caíram repentinamente, essa aristocracia se viu sem nenhuma outra fonte de sustento e sem dinheiro para buscar outros investimentos.

Nesse momento quem tinha algum dinheiro, mesmo que pouco, pode multiplicá-lo rapidamente, cedendo empréstimos a esses desesperados monocultores que certamente não teriam dinheiro para pagá-los, pois a maioria deles não sabia fazer outra coisa que não plantar café. Desta forma a importância do empréstimo acabava sendo dissipada nos gastos domésticos, assim os bens penhorados eram tomados com valores muito abaixo do valor real.

São nessas posições que encontramos os personagens principais dessa peça. Abelardo I é um novo rico que ganhou muito dinheiro fazendo empréstimos aos proprietários falidos.

CLIENTE - Eu era um proprietário quando vim aqui a primeira vez. 
ABELARDO I - Veja! Isto não é comercial! Seu Pitanga! O senhor fez o primeiro empréstimo em fins de 29. (ANDRADE, 1967, p. 39)

Contudo não se contenta em possuir o dinheiro, quer também o status social dos aristocratas. Por isso quer casar com Heloísa.

ABELARDO I (Rindo) - Você! Meu Amor! Na hora do expediente!

HELOÍSA - O nosso casamento é um negócio... [...] como os que você faz com esse bando desesperados saiu daí vociferando... (ANDRADE, 1967, p. 49)

Heloísa é uma aristocrata de família falida. Seus parentes decaíram com a crise do café e empenharam seus bens, depois não puderam mais se restabelecer. Atualmente a família de Heloísa não tem dinheiro nenhum, por isso ela quer casar com Abelardo, para ter o dinheiro necessário à sobrevivência de sua família e seus hábitos nobres.

HELOÍSA - Meus pais... meus tios...meus primos...

ABELARDO I - Os velhos senhores da terra tiveram que dar lugar aos novos senhores da terra!

HELOÍSA - No entanto todos dizem que acabou a época dos senhores e latifúndios...

ABELARDO I - Você sabe que o meu caso prova o contrário. Ainda não tenho o número de fazendas que seu pai tinha, mas já possuo área cultivada maior que a que ele teve no tempo do apogeu. (ANDRADE, 1967, p. 55)

Há também outra passagem extremamente pertinente para ilustrar as posições sociais desses dois protagonistas: "HELOÍSA - Você é realista. E por isso enriqueceu magicamente. Enquanto os meus, lavradores de cem anos, empobreceram em dois...” (ANDRADE, 1967, p. 53)

A peça de Oswald de Andrade $O$ Rei da Vela foi publicada em 1933, mas só em 1967 foi aos palcos. Passando pela censura num momento bem próximo ao de maior grau de repressão no país. Bom, aqui está a grande interrogação: Como uma peça com a carga crítica tão grande aos pilares da ditadura alcançou a encenação nesse momento? "Para a surpresa de todos, a presença cultural de esquerda não foi liquidada [...] Apesar da ditadura de direita há uma relativa hegemonia cultural de esquerda no país.” (SCHWARTZ,1978, p. 62)

Fique bem claro que essa hegemonia cultural era muito bem encistada nos grupos diretamente ligados à produção cultural. $\mathrm{O}$ que realmente era peremptoriamente banido era qualquer contato com as massas. (cf. SCHWARTZ, 1978, p. 62) A peça, digamos assim, foi minuciosamente escolhida para encenação nesse período, visto que as maiores críticas contidas nela são direcionadas a alguns fatores capitais desse momento:

\section{$\mathbf{1}^{\circ}$ - A igreja}

ABELARDO I —Bom dia, reverendo! Sou eu mesmo. Abelardo... Ah! Com muitíssima honra [...] Beijo-lhe as mãos! Este padre é engraçado... Ele não quer dinheiro...”.

ABELARDO II - Quer sua alma... [...]

ABELARDO I - Inútil. Eu morro ateu e casado. (ANDRADE, 1967, p. 46) 
Com esse fator começamos a montar o tripé mais citado em relação à ditadura de 64 . A primeira crítica é ao padre que, segundo os personagens, mesmo que procure não aparentar, também quer dinheiro, mas não em empréstimos como os outros ele quer vender a salvação. O padre, apesar de disfarçar mais, quer que Abelardo deixe em herança seus bens para a igreja. Abelardo, por sua vez é cínico para com o padre, pois aparenta respeitá-lo e acreditar nos seus divinos propósitos, enquanto sabe dos verdadeiros motivos da atenção do padre.

\section{$2^{\circ}$ - Estado}

A pátria é vista no texto como pobre e subordinada aos países ricos. Não é em nenhum momento exaltada como a ditadura prega, antes pelo contrário, é motivo de chacota e deboche. É vista pelo protagonista como atrasada e pobre, frente às maiores só deve mesmo respeito e subordinação.

HELOÍSA - Eu li num jornal que devemos só a Inglaterra trezentos milhões de libras, mas só chegaram até aqui trinta milhões...

ABELARDO I - É provável! Mas compromisso é compromisso! Os países inferiores têm que trabalhar para os países superiores como os pobres trabalham para os ricos. (ANDRADE, 1967, p. 55)

\section{$3^{\circ}-$ Família}

ABELARDO I - Não confunda, Seu Abelardo! Família é uma coisa distinta. Prole é de proletariado. A família requer a propriedade e vice- versa. Quem não tem propriedade deve ter prole. Para trabalhar, os filhos são a fortuna do pobre ... (ANDRADE, 1967, p. 41)

O último pé é então a família, na peça, assustadoramente (as mentes pequeno burguesas) ligada à existência da propriedade. A família perde sua aura religiosa e fica ligada exclusivamente a manutenção da atual ordem social desigual e injusta e principalmente ligada à manutenção da propriedade, como Abelardo explica quando fala a respeito do casamento.

HELOÍSA - Em troca da minha liberdade. Chegamos ao casamento... Que você no começo dizia ser a mais imoral das instituições.

ABELARDO I - E a mais útil à nossa classe... A que defende a herança... (ANDRADE, 1967, p. 53)

Também degenera a visão da estrutura familiar de Heloísa, sua família apesar de gozar de esplendido status, guarda toda série de 'anomalias' recusadas pela sociedade de então, além das citadas ainda estão o homossexualismo de Totó bem explícito, e o de Heloísa disfarçado por seus relacionamentos com homens.

HELOÍSA (sonhando) - Meu pai era o Coronel Belarmino que tinha sete fazendas, aquela casa suntuosa de Higienópolis... ações, automóveis... Duas filhas viciadas, dois filhos tarados... ficou morando na Penha e indo à missa pedir a Deus a solução que os governos não deram... (ANDRADE, 1967, p. 54)

Quase concluindo o rol de críticas temos a crítica aos sistemas de administração, o primeiro atacado é o fascismo. 
ABELARDO I - Somos parte de um todo ameaçado - o mundo capitalista. Se os banqueiros imperialistas quiserem... Você sabe, há um momento em que a burguesia abandona sua velha máscara liberal. Declara-se cansada de carregar nos ombros os ideais de justiça da humanidade, as conquistas da civilização e outras besteiras! Organiza-se como classe. Policialmente. Esse momento já soou na Itália e implanta-se pouco a pouco nos países onde o proletariado é fraco ou dividido. (ANDRADE, 1967, p. 75)

Lê-se nessa fala que o locutor pensa que,se a burguesia tomar essa atitude, ela está no seu direito. Isso quer dizer que Abelardo acredita que a salvação para sua propriedade frente ao fantasma do comunismo é o fascismo. Tanto que ao fim Abelardo chega a ajudar na formação de milícias para proteger as fazendas. Abelardo vê o Brasil como um país onde o proletariado é fraco e dividido por isso um possível candidato aos regimes totalitaristas de direita, aliás como ocorrerá no governo de Vargas, não chegando ao ponto que atingiu na Europa, mas com uma tendência fascista bem forte.

Também são criticadas as leis sociais, nesse momento (o momento que estamos tratando aqui, ou seja, o golpe de 64) podem ser lidas como críticas ao governo de Goulart antecessor do regime militar, mas na época em que a peça foi escrita está relacionada ao paternalismo de Vargas. O autor mostra que essas leis sociais são elaboradas somente para apaziguar o povo que na realidade não ganha nada com elas.

ABELARDO I - O salário mínimo. As férias. Que diabo. As tais leis sociais não hão de ser só contra o capital...

ABELARDO II - Não são não. Descanse. Eu entendo de socialismo. Olhe. A lei de férias só deu um resultado. Não há mais salário de semana ou mês. É por dia de trabalho, ou por contrato. Somando bem, os domingos, feriados e dias de doença eram mais que as férias de hoje. (ANDRADE, 1967, p. 48)

Mas, as formas personificadas na peça são: o capitalismo e socialismo; encarnados nos representantes do poder: ABELARDO I e ABELARDO II.

ABELARDO I - A polícia ainda existe ...

CLIENTE - Para defender os capitalistas! E os seus crimes!

ABELARDO I - Para defender o meu dinheiro. Será executado hoje mesmo. (ANDRADE, 1967, p. 41)

Deste trecho lemos que o primeiro Abelardo representa o capitalismo. O protagonista se assume como capitalista quando admite que a polícia existe para defender o seu dinheiro. Além disso, podemos crer que o capitalismo que Abelardo defende é o fascismo, pois defende o uso da força policial para defender seu direitos.

ABELARDO I - Diga-me uma coisa, Seu Abelardo, você é socialista?

ABELARDO II - Sou o primeiro socialista que aparece no Teatro Brasileiro. [...]

ABELARDO I - Pelo que vejo o socialismo nos países atrasados começa logo assim... Entrando num acordo com a propriedade.

ABELARDO II - Sim. Sem quebrar a tradição. (ANDRADE, 1967, p. 47)

Assim, o segundo Abelardo é identificado com o socialismo, mas não com o socialismo "utopisado", e sim com o socialismo real que se implantou verdadeiramente com 
todos seus desmandos e defeitos. É clara a crítica a qualquer forma de poder; não há engajamento do autor em nenhum deles, só há crítica.

Por fim, ocorre a morte de Abelardo I, Abelardo II o rouba e enfim toma o seu lugar: o socialismo toma o lugar do capitalismo, contudo não há nenhuma mudança real. Afinal Abelardo sempre fica com Heloísa, ou seja o poder está sempre nas mesmas mãos, de qualquer forma (leia-se: em qualquer forma de governo).

A velha aristocracia nunca cairá, mesmo sem dinheiro sempre estarão aliados ao poder e por isso sempre terão seu espaço garantido no topo da pirâmide social; os pobres sempre serão, de alguma maneira, pobres (como ocorreu no enriquecimento de Abelardo I sempre lhe ficou faltando o sobrenome), mas os realmente miseráveis nem tomarão conhecimento das mudanças no poder, pois essas mudanças nunca chegarão a mudar sua circunstância de vida.

ABELARDO II - Está morrendo. A minha vida começa! [...]

ABELARDO I (num esforço enorme) - A vela! [...]

ABELARDO II - Ahn! Quer morrer de vela na mão? [...] Não quer perder a majestade.

HELOÍSA (levantando entre soluços enormes) - Abelardo! Abelardo!

ABELARDO II - Heloísa será sempre de Abelardo. É clássico! (ANDRADE, 1967, p. 88)

Por fim o texto é totalmente crítico: ele não crê em nenhuma forma de governo, mas a mais criticada, em todas suas formulações é a ditadura militar do Brasil que começou a se definir na revolução de 30 e se estabeleceu no golpe de 64 .

\section{Referências}

ANDRADE, Oswald de. O rei da vela. In: ANDRADE, Oswald de. Obras Completas de Oswald de Andrade, São Paulo: Globo, 1967.

DUARTE, Eduardo de Assis. Oswald de Andrade e a cena semiótica d'O rei da vela. In: Semiótica da literatura. São Paulo: Educ, 1987. p. 101-107.

SCHWARZ, Roberto. O pai de família e outros estudos. Rio de Janeiro: Paz e Terra, 1978.

SILVA, Helio Ribeiro da. 1964 : vinte anos de golpe militar. Porto Alegre: L\&PM, 1985.

TOLEDO, Caio Navarro de. O governo Goulart e o golpe de 64. 10. ed. São Paulo: Brasiliense, 1989. 